\title{
Progenitor/Stem Cell Engineering for Treatment of Ischemic Heart Diseases: Therapeutic Potentials and Challenges
}

\author{
Yuliang Feng, Yigang Wang and Shi-Zheng Wu \\ Additional information is available at the end of the chapter
}

http://dx.doi.org/10.5772/53517

\section{Introduction}

\subsection{Treatment for ischemic heart diseases: State-of-the-art}

Cardiovascular diseases, especially ischemic heart disease, are the leading cause of mortality in the United States [1]. In the past decades, pharmacological therapy, such as $\beta$-blocker, Angiotensin Converting Enzyme Inhibitor (ACEI)/Angiotensin Receptor Blocker(ARB) have been shown to ameliorate cardiac dysfunction and limit heart remodeling following myocardial infarction [2]. Moreover, the development of coronary artery bypass graft (CABG) can recanalize occlusive coronary and salvage the remaining surviving myocardium [3]. More recently, with the development of percutaneous coronary intervention (PCI), retrograde approach through collaterals has been introduced for percutaneous recanalization of chronic total occlusion (CTO) of the coronary arteries, a new option for the patient with CTO beyond CABG [4]. Unfortunately, even with great advances of these modern technologies, myocardial infarctions will eventually develop into decompensated chronic heart failure. Heart transplantation is currently the last resort for the patient with end-stage heart failure. However, this therapeutic option is limited by donor organ shortage and eventual organ rejection [5]. Therefore, new therapies are required to prevent the progression of pathological remodeling and cell death, as well as to induce tissue recovery in the ischemic heart. Regenerative cardiovascular medicine becomes a holy grail with the goal to replace and repair the damaged myocardium and reverse heart dysfunction. In the past two decades, a variety of stem cells have been investigated by scientists to achieve this goal [6]. Recently developed reprogramming technology, induced pluripotent stem cells (iPSC) has become an alternative source for embryonic stem cells (ESC) without the ethical drawbacks [7], showing their powerful 
potential to differentiate into desired cell type [8]. A new discipline termed stem cell engineering has recently emerged aiming to reconstruct the damaged heart by integrating progenitor/stem cell biology and bioengineering technology [9]. In this chapter, the recent the recent advances and challenges of progenitor/stem cell engineering for the therapy of ischemic heart disease will be discussed from a translational perspective.

\section{Proper cell sources}

Appropriate cell sources for stem cell engineering must meet the following requirements: 1) The cell must be electromechanically coupled with the host heart tissue. 2) They must survive in the hostile environment created by ischemic stress [10]. In this regard, several cell types have been tried. Skeletal myoblast was the pioneering attempt but it was found to be limited to contract synchronously with the host myocardium [11]. Bone marrow derived stem cells or hematopoietic stem cells are easily obtained in clinical setting but their potential of cardiogenic differentiation is still being debated [10]. The recent discovery of multipotent cardiac progenitors have been proven to give rise to cardiomyocytes, endothelial, and smooth muscle cells, forming the basic "components" for heart reconstruction [12]. The attempt to discover endogenous cardiac progenitors showed some of those express c-Kit [13, 14] or Sca-1 [14] markers. Transplantation of $\mathrm{c}-\mathrm{Kit}^{+}$cell resulted in neovascularization and cardiomyogenesis in the infarcted heart [13]. Moreover, the cardiosphere obtained from human heart tissue contained a mixed population of c-Kit ${ }^{+}$and Sca- $1^{+}$cells and could regenerate infarcted heart [15]. These encouraging results led to the initiation of several phase 1 clinical trials: ALCADIA ((AutoLogous Human CArdiac-Derived Stem Cell to Treat Ischemic cArdiomyopathy, NCT00981006), SCIPIO (Cardiac Stem Cell Infusion in Patients with Ischemic Cardiomyopathy) (NCT00474461), and CADUCEUS (NCT00893360). Preliminary data from the SCIPIO and CADUCEUS (CArdiosphere-Derived aUtologous Stem CElls to Reverse ventricUlar dysfunction) trials have been recently published in the Lancet [16, 17]. Both studies were aimed to evaluate the feasibility and safety of intracoronary injection of autologous heart-derived cells in a patient post myocardial infarction. The SCIPIO study [16] used c-kit ${ }^{+}$cells that were cultured from atrial tissue, whereas the CADUCEUS study [17] is using cardiospheres cultured from biopsy-obtained right ventricular tissue. There is no report related to severe side effect associated with cardiac cell injection in these two studies, although more adverse events were observed in CADUCEUS study (treatment group). Both studies reported reduction in infarct size following cell injection, but only the SCIPIO trial reported an improvement in left ventricular ejection fraction (LVEF). There are still some limitations in these results, as indicated by the limited sample size (16 in SCIPIO and 17 in CADUCEUS) and the absence of a placebo group. Therefore, phase 2 study must be initiated in the future to further confirm its safety and efficacy.

Furthermore, stimulation of the adult progenitor pool with epicardial origin after an acute myocardial infarction (AMI) has been reported with some progress [18-20]. The successful production of iPSC by transducing pluripotent-regulated transcriptional factors has made it a powerful weapon for ex vivo expansion of cardiomyocytes [21]. And the direct 
differentiation of pluripotent stem cells can be enhanced by administration of BMP4 and activin A $[22,23]$. How to remove undifferentiated stem cells from differentiated cardiomyocytes has been a major challenge in translational cardiovascular medicine. Potential solutions to this problem might be can be overcome by i) purification of isl- $1^{+}$ventricular precursors followed by committed differentiation [24] or ii) transgenic enrichment via negative selection of iPSC using a suicide gene (thymidine kinase)/positive selection of cardiomyocytes expressing a bicistronic reporter GFP expression under control of alpha myosin heavy chain promoter [25]. Taken together, these cells provide a valuable source for generation of a cell sheet/patch for tissue engineering purpose. Therefore, there are two techniques commonly used for cardiac repair. The first is transplantation of stem cells with cardiogenic potential into injured heart or pre-induction of stem cells into cardiomyocytes followed by implantation. The second is stimulation of the endogenous cardiac progenitor pool to propagate cardiovascular offspring. More recently, the laboratories of Deepak Srivastava and Eric Olson reported a new method, termed by "in vivo reprogramming of cardiomyocytes", making in vivo transformation of scar tissue into beating heart muscle possible. By transducing with retroviruses encoding GMT (GATA4, MEF2C, TBX5) [26] or GMTH (GMT+Hand2) [27] in vivo following left anterior descending artery (LAD) ligation, cardiac fibroblasts, the natural "partner" of cardiomyocytes, become activated, migrate to the injured site, and proliferate, thus rendering these cells susceptible to retroviral infection and subsequent epigenetic reprogramming event. Both groups reported a significant conversion of transduced fibroblasts, identified by genetic lineage tracing of non-cardiomyocyte in the heart, to an "induced cardiomyocyte-like (iCM)" or "induced cardiac-like myocyte (iCLM)" state iCMs/iCLMs. Although without presence of rhythm disorder in mice, it is necessary to test the approach in pigs, whose hearts are similar to those of human in terms of size and physiology, to further evaluate its efficacy and safety before clinical trial.

\section{Engineering approach}

Direct injection of cell suspension into infarcted area or peri-infarcted area is still the main progenitor/stem cell treatment used for cardiac repair. Nevertheless, the poor survival of stem cells in the harsh environment (hypoxia, inflammatory cytokines, etc.) limits the reparative function of progenitor/stem cells in ischemic heart [28].

Combining progenitor/stem cell biology and bioengineering, tissue engineering holds great promise to generate viable three dimensional heart tissue with vasculature prior to engraftment to the heart, as an integral part of the host. This tissue graft should display contractile and electromechanical coupled properties, contributing to the improvement of heart function. The recent evidence from large animals indicated that human ES-derived cardiomyocytes electrically coupled and suppressed arrhythmias in injured hearts. This provided support for the continued development of human stem cell derived tissue graft for cardiac repair [29]. The conventional approach involved seeding cell on scaffolds and culture in vitro prior to implantation. 
Eschenhagen and Zimmermann constructed an engineering heart tissue (EHT) by seeding neonatal rat cardiomyocytes and a mix of collagen I, extracellular matrix proteins (Matrigel) into a lattices or circular molds. Upon spontaneous remodeling of the liquid reconstitution mixture and cyclic mechanical, EHT spontaneously and synchronously contracted after one to two weeks of cultivation, which highlights the great importance of physical stimulation on the maintenance of the physical and mechanical function of EHT [30]. This pioneering work for the first time showed EHT could ameliorate cardiac function post MI.

\subsection{Scaffold free tissue construct}

The use of cell sheets provides a simple scaffold-free approach by seeding cardiac cells on poly (N-isopropylacrylamide)-grafted polystyrene dishes and then lowering the temperature to $20^{\circ} \mathrm{C}$, thus inducing the detachment of intact cell monolayers without enzymatic digestion. Using this method, a 1-mm-thick cell patch can be created by serial stacking of multiple monolayer sheets [31]. A recent study by Murry group using ESC-derived cardiomyocytes reported another scaffold free approach, demonstrating cell aggregation is sufficient to generate functional EHT also showing endothelial cell and fibroblast are required for the survival and integration of EHT and in host myocardium [32]. Further studies are needed to optimize the proportion of cardiomyocyte, endothelial cells, and fibroblast for maximal performance of EHT.

\subsection{Construction of myocardial tissue/heart using decellularized native tissue}

In order to create decellularized scaffolds, Taylor and her team perfused rat hearts with detergents to remove the cells and leave a complex architecture of acellular extracellular matrix (ECM) behind. [33]. This native scaffold was reseeded with cardiomyocytes and endothelial cells taken from rats. They then placed these constructs in bioreactors that simulated blood pressure, electrical stimulation, and other aspects of cardiac physiology to assure integration of the scaffold and seeded cells. Although approximately only $2 \%$ of normal contractile activity was acquired from this approach, this is a successful proof-ofconcept trial and might be the ultimate biomimetic method for constructing an intact human heart.

\subsection{Porous scaffolds}

By using electrical stimulation, Vunjak-Novakovic et al., established a method to assemble individual cardiomyocytes into a functional cell patch [34]. The hydrogel-encapsulated neonatal rat heart cells were cultivated on porous collagen scaffolds. Currently, this methodology has been applied in other cell types (e.g. hESC) [35] and with other scaffold material (e.g. synthetic elastomers) [36]. 3 days before electrical stimulation, the cells were cultured in petri dishes to allow sufficient expression of gap junction protein (e.g. Cx43) and other molecules involved in contraction. Then the cells were subjected to electrical stimulation to induce synchronous contraction and alteration of structural organization, resulting in the formation of mature myocardium with elongated, viable cells aligned in parallel. 


\subsection{Biological and synthetic polymers}

Collagen is the first biological polymer used for fabrication of three dimensional tissues. It was reported that neonatal rat cardiomyocytes spontaneously contracted when cultivated in gelatin coated scaffold. Although the implanted cardiomyocytes survived in infarcted heart, LVEF is not significantly improved after long term observation. Furthermore, Zimmermann's group engineered contractile 3-D heart tissue, in which cardiomyocytes encapsulated with ring--shaped hydrogels (collagen and Matrigel) showing reduction of ventricle dilatation, significant ventricular wall thickening and improvement of the fractional shortening (FS) [30]. The improvement of cardiac function, myofibril organization indicated that mechanical stimulation is important for maturation of myocardial structure. Leor et al. also reported that 3-D alginate scaffolds seeded with fetal rat cardiomyocytes attenuated left ventricular dilatation and deterioration of the heart function after myocardial infarction [37].

\section{Progenitor/stem cell niche engineering}

As we discussed above, the laboratories of Deepak Srivastava and Eric Olson were successful in reprogramming cardiac fibroblasts in vivo into cardiomyocytes with a significant efficiency. In 2010, Deepak's team attempted to reprogram cardiac fibroblast into cardiomyocytes with the same combination of transcription factors in vitro but experienced low efficiency [38], while recently Sean M. Wu's team reported in some cases, the reprogramming is still inefficiency [39]. The great difference with respect to reprogramming efficiency in vitro and in vivo using the same transcription factor cocktail suggested that the local microenvironment (niche) is a critical checkpoint for cell reprogramming and regeneration. In vivo, the stem cell niche is a complex and dynamic unit, and how these components interact to modulate progenitor/stem cell fate is on the horizon to be understood. Alteration of the properties of progenitor/stem cell niches may provide new therapeutic strategies for progenitor/stem cell engineering by interrupting cardiac remodeling or accelerating the reparative process. Here we discuss two key expects of progenitor/stem cell niche, namely mechanical cue and chemical cues and their implication for progenitor/stem cell engineering.

\subsection{Matrix rigidity}

Progenitor/stem cell engineering involves coordination of selective proliferation of precursor/ stem cells and differentiation into target somatic cells (cardiomyocytes, smooth muscle cell, and endothelial cells). Mechanical cues influence proliferation, differentiation, migration, and spatial morphological organization. These cues include the rigidity of the surrounding matrix or cell adhesion substratum. Thus, better understanding of the role of matrix rigidity is critical for optimization of the regimes of mechanical conditioning of cultured tissue constructs. Based on a pioneering study which discovered mechanosensitive transcriptional mechanism in 2009 [40], Kshitiz et al showed that resident cardiac progenitor cells continually monitored cell substratum rigidity and demonstrated enhanced proliferation, endothelial differentiation, and morphogenesis when the cell substratum rigidity closely matched that of myocardium [41]. 
This process is mediated by p190RhoGAP, a guanosine triphosphatase-activating protein for RhoA, acting through RhoA-dependent and -independent mechanisms. Downregulation of p190RhoGAP triggered a series of developmental events by coupling cell-cell and cellsubstratum interactions to genetic circuits controlling differentiation. Hence, preconditioning of endothelial progenitors could change p190RhoGAP abundance and thus promote angiogenesis in engrafted heart. More generally, the results suggest the importance of the feedback between the rigidity of a developing or regenerating tissue and the control of cell growth and differentiation, which may be critical for adaptive development and maintenance of structurally complex tissues and organs.

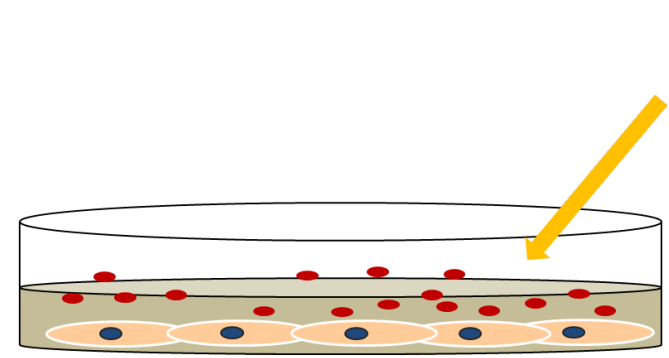

\section{Exosome providing} miRs,GFs,cytokines, etc.

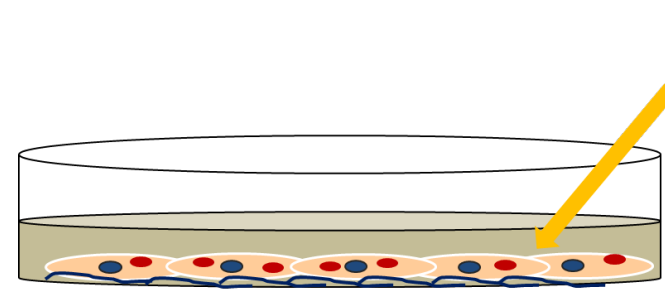

\section{ECM providing optimal matrix rigidity.}

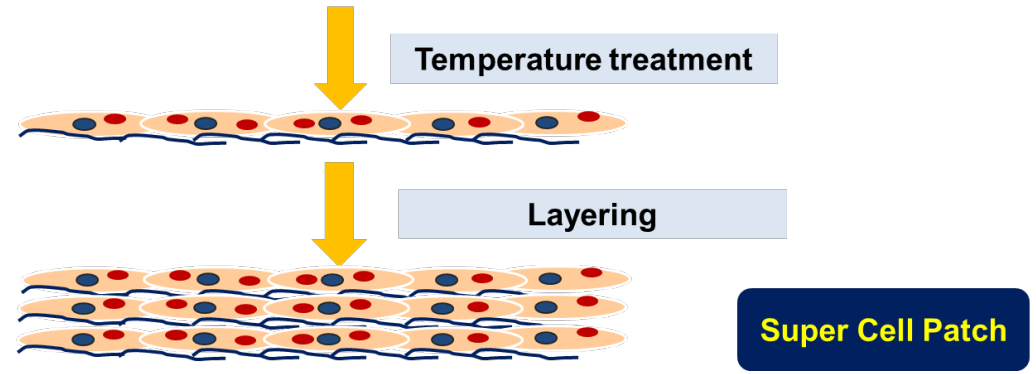

Figure 1. Fabrication of "Super Cell Patch". Progenitor/cells were treated with exosome containing microRNAs (miRs), growth factors (GFs) and cytokines etc. Then the progenitor/stem cells were administered with optimized ECM to provide the suitable matrix rigidity for engraftment. Subsequently, confluent cells forming sheets were released from the dish surface by decreasing temperature from $37^{\circ} \mathrm{C}$ to $20^{\circ} \mathrm{C}$. Then, several cell sheets were stratified and placed across the epicardial surface of infarcted myocardium to form a functional bridge for the purpose of restoring global contractile function. 


\subsection{Exosome secretion}

Recent studies have suggested four potential mechanisms for how exogenous-cultureexpanded MSC may contribute to cardiovascular repair: transdifferentiation, cell fusion with a native cell, stimulation of endogenous cardiac progenitor/stem cells via direct cell-cell communication or paracrine mechanism [42]. Transdifferentiation of MSC into cardiomyocytes is not inefficient in current regimes [10]. Cell fusion is a rare event[43]. As aforementioned, the observed salutary effects of progenitor/stem cell on cardiac repair probably resulted from paracrine mechanism. And the cardiogenic differentiation of CSC stimulated by MSC processed a limited capacity [44]. By antibody array and Liquid Chromatography with Tandem Mass Spectrometry Detection (LC-MS/MS), compelling evidences have shown MSC could secrete a wide spectrum of trophic proteins that could induce proliferation and differentiation of CPC and angiogenesis [45]. Interestingly, in 2007, the paper published on Nature Cell Biology revealed mRNAs and microRNAs in the exosome (the major microvesicle for intercellular communication) can be delivered from one cell to another, and can be functional in this new location [46]. This hallmark study elicited amazing expansion of studies on exosomes in the last 3 years, making it a very exciting field now. A recent study has targeted exosomes to the brain to treat Alzheimer's disease by engineering exosomes with dendrite cells marker [47]. This study highlighted the possibility that cardiac-specific exosomes can be engineered to treat ischemic heart diseases without any risk of immunorejection or carcinogenesis by viral infection. Thus, compared to the delivery of single growth factors or cytokines, the direct administration of exosomes derived from preconditioned progenitors/stem cells into ischemic heart or using cell sheet/patch modified with preconditioned exosomes might be a new trend to improve cardiac repair in a more efficient way (Fig. 1).

\section{Conclusions}

Progenitor/stem cell engineering has presented as an exciting and promising avenue for the treatment of ischemic heart diseases. Regeneration of damaged heart by progenitor/stem cell engineering is becoming a fact rather than fiction. The translation of experimental discovery in progenitor/stem cell engineering into clinical application should be accelerated and large scale clinical trials should be initiated in the patients with ischemic heart diseases. Therefore, the collaboration of progenitor/stem cell biologists, bioengineers, and physicians is possibly the future modality in personalized regenerative medicine.

\section{Acknowledgements}

Funding sources

This work was supported by NIH grants, HL089824, HL081859, HL110740 (Y. Wang).

Mianna Armstrong for technical assistance. 


\section{Author details}

Yuliang Feng ${ }^{1,2}$, Yigang Wang ${ }^{1 *}$ and Shi-Zheng $\mathrm{Wu}^{3}$

*Address all correspondence to: yi-gang.wang @uc.edu

1 Department of Pathology and Laboratory Medicine, College of Medicine, University of Cincinnati, Cincinnati, Ohio, USA

2 Medical Research Center of Guangdong General Hospital, Guangdong Academy of Medical Sciences, Guangdong Provincial Cardiovascular Institute, Southern Medical University, Guangzhou, China

3 Qinghai Provincial People's Hospital, Qinghai Clinical Medical Institute, Xining, Qinghai, China

\section{References}

[1] Roger, V. L, Go, A. S, Lloyd-jones, D. M, Adams, R. J, Berry, J. D, Brown, T. M, et al. Heart disease and stroke statistics--2011 update: a report from the American Heart Association. Circulation. (Journal Article). (2011). e, 18-209.

[2] Adding ACEIs and/or ARBs to Standard Therapy for Stable Ischemic Heart Disease: Benefits and HarmsBook Chapter). (2007).

[3] Mcmurray, J. J. Heart failure in 2011: Heart failure therapy--technology to the fore. Nat Rev Cardiol. (Journal Article; Review). (2012). , 9(2), 73-4.

[4] Jones, D. A, Weerackody, R, Rathod, K, Behar, J, Gallagher, S, Knight, C. J, et al. Successful recanalization of chronic total occlusions is associated with improved longterm survival. JACC Cardiovasc Interv. (Journal Article). (2012). , 5(4), 380-8.

[5] Jessup, M, Albert, N. M, Lanfear, D. E, Lindenfeld, J, Massie, B. M, Walsh, M. N, et al. ACCF/AHA/HFSA 2011 survey results: current staffing profile of heart failure programs, including programs that perform heart transplant and mechanical circulatory support device implantation. J Card Fail. (Comparative Study; Journal Article; Multicenter Study). (2011). , 17(5), 349-58.

[6] Ptaszek, L. M, Mansour, M, Ruskin, J. N, \& Chien, K. R. Towards regenerative therapy for cardiac disease. Lancet. (Journal Article; Research Support, Non-U.S. Gov't; Review). (2012). , 379(9819), 933-42.

[7] Takahashi, K, Tanabe, K, Ohnuki, M, Narita, M, Ichisaka, T, Tomoda, K, et al. Induction of pluripotent stem cells from adult human fibroblasts by defined factors. Cell. (Journal Article; Research Support, Non-U.S. Gov't). (2007). , 131(5), 861-72. 
[8] Bilic, J, \& Izpisua, B. J. Concise review: Induced pluripotent stem cells versus embryonic stem cells: close enough or yet too far apart? Stem Cells. (Journal Article; Research Support, Non-U.S. Gov't; Review). (2012). , 30(1), 33-41.

[9] Sui, R, Liao, X, Zhou, X, \& Tan, Q. The current status of engineering myocardial tissue. Stem Cell Rev. (Journal Article; Review). (2011). , 7(1), 172-80.

[10] Laflamme, M. A, \& Murry, C. E. Heart regeneration. Nature. (Journal Article; Research Support, N.I.H., Extramural; Review). (2011). , 473(7347), 326-35.

[11] Formigli, L, Zecchi-orlandini, S, Meacci, E, \& Bani, D. Skeletal myoblasts for heart regeneration and repair: state of the art and perspectives on the mechanisms for functional cardiac benefits. Curr Pharm Des. (Journal Article; Review). (2010). , 16(8), 915-28.

[12] Hansson, E. M, Lindsay, M. E, \& Chien, K. R. Regeneration next: toward heart stem cell therapeutics. Cell Stem Cell. (Journal Article; Research Support, N.I.H., Extramural; Research Support, Non-U.S. Gov't; Review). (2009). , 5(4), 364-77.

[13] Beltrami, A. P, Barlucchi, L, Torella, D, Baker, M, Limana, F, Chimenti, S, et al. Adult cardiac stem cells are multipotent and support myocardial regeneration. Cell. (Journal Article; Research Support, U.S. Gov't, P.H.S.). (2003). , 114(6), 763-76.

[14] Oh, H, Bradfute, S. B, Gallardo, T. D, Nakamura, T, Gaussin, V, Mishina, Y, et al. Cardiac progenitor cells from adult myocardium: homing, differentiation, and fusion after infarction. Proc Natl Acad Sci U S A. (In Vitro; Journal Article; Research Support, Non-U.S. Gov't; Research Support, U.S. Gov't, P.H.S.). (2003). , 100(21), 12313-8.

[15] Chimenti, I, Smith, R. R, Li, T. S, Gerstenblith, G, Messina, E, Giacomello, A, et al. Relative roles of direct regeneration versus paracrine effects of human cardiospherederived cells transplanted into infarcted mice. Circ Res. (Journal Article; Research Support, N.I.H., Extramural; Research Support, Non-U.S. Gov't). (2010). , 106(5), 971-80.

[16] Bolli, R, Chugh, A. R, Amario, D, Loughran, D, Stoddard, J. H, \& Ikram, M. F. S, et al. Cardiac stem cells in patients with ischaemic cardiomyopathy (SCIPIO): initial results of a randomised phase 1 trial. Lancet. (Clinical Trial, Phase I; Journal Article; Randomized Controlled Trial; Research Support, N.I.H., Extramural; Research Support, Non-U.S. Gov't). (2011). , 378(9806), 1847-57.

[17] Makkar, R. R, Smith, R. R, Cheng, K, Malliaras, K, Thomson, L. E, Berman, D, et al. Intracoronary cardiosphere-derived cells for heart regeneration after myocardial infarction (CADUCEUS): a prospective, randomised phase 1 trial. Lancet. (Clinical Trial, Phase I; Journal Article; Multicenter Study; Randomized Controlled Trial; Research Support, N.I.H., Extramural; Research Support, Non-U.S. Gov't). (2012). , 379(9819), 895-904.

[18] Zhou, B, Ma, Q, Rajagopal, S, Wu, S. M, Domian, I, Rivera-feliciano, J, et al. Epicardial progenitors contribute to the cardiomyocyte lineage in the developing heart. Na- 
ture. (Journal Article; Research Support, N.I.H., Extramural; Research Support, NonU.S. Gov't). (2008). , 454(7200), 109-13.

[19] Smart, N, Bollini, S, Dube, K. N, Vieira, J. M, Zhou, B, Davidson, S, et al. De novo cardiomyocytes from within the activated adult heart after injury. Nature. (Journal Article; Research Support, Non-U.S. Gov't). (2011). , 474(7353), 640-4.

[20] Zhou, B, Honor, L. B, He, H, Ma, Q, Oh, J. H, Butterfield, C, et al. Adult mouse epicardium modulates myocardial injury by secreting paracrine factors. J Clin Invest. (Journal Article; Research Support, N.I.H., Extramural; Research Support, Non-U.S. Gov't). (2011). , 121(5), 1894-904.

[21] Burridge, P. W, Keller, G, Gold, J. D, \& Wu, J. C. Production of de novo cardiomyocytes: human pluripotent stem cell differentiation and direct reprogramming. Cell Stem Cell. (Journal Article; Research Support, N.I.H., Extramural; Research Support, Non-U.S. Gov't). (2012). , 10(1), 16-28.

[22] Yang, L, Soonpaa, M. H, Adler, E. D, Roepke, T. K, Kattman, S. J, Kennedy, M, et al. Human cardiovascular progenitor cells develop from a KDR+ embryonic-stem-cellderived population. Nature. (Journal Article; Research Support, N.I.H., Extramural). (2008). , 453(7194), 524-8.

[23] Laflamme, M. A, Chen, K. Y, Naumova, A. V, Muskheli, V, Fugate, J. A, Dupras, S. K, et al. Cardiomyocytes derived from human embryonic stem cells in pro-survival factors enhance function of infarcted rat hearts. Nat Biotechnol. (Journal Article; Research Support, N.I.H., Extramural; Research Support, Non-U.S. Gov't). (2007). , 25(9), 1015-24.

[24] Moretti, A, Bellin, M, Jung, C. B, Thies, T. M, Takashima, Y, Bernshausen, A, et al. Mouse and human induced pluripotent stem cells as a source for multipotent Isl1+ cardiovascular progenitors. Faseb J. (Journal Article; Research Support, Non-U.S. Gov't). (2010). , 24(3), 700-11.

[25] Cheng, F, Ke, Q, Chen, F, Cai, B, Gao, Y, Ye, C, et al. Protecting against wayward human induced pluripotent stem cells with a suicide gene. Biomaterials. (Journal Article; Research Support, Non-U.S. Gov't). (2012). , 33(11), 3195-204.

[26] Qian, L, Huang, Y, Spencer, C. I, Foley, A, Vedantham, V, Liu, L, et al. In vivo reprogramming of murine cardiac fibroblasts into induced cardiomyocytes. Nature. (Journal Article; Research Support, N.I.H., Extramural; Research Support, Non-U.S. Gov't). (2012). , 485(7400), 593-8.

[27] Song, K, Nam, Y. J, Luo, X, Qi, X, Tan, W, Huang, G. N, et al. Heart repair by reprogramming non-myocytes with cardiac transcription factors. Nature. (Journal Article; Research Support, N.I.H., Extramural; Research Support, Non-U.S. Gov't). (2012). , 485(7400), 599-604. 
[28] Choi, S. H, Jung, S. Y, Kwon, S. M, \& Baek, S. H. Perspectives on stem cell therapy for cardiac regeneration. Advances and challenges. Circ J. (Journal Article; Research Support, Non-U.S. Gov't). (2012). , 76(6), 1307-12.

[29] Shiba, Y, Fernandes, S, Zhu, W. Z, Filice, D, Muskheli, V, Kim, J, et al. Human EScell-derived cardiomyocytes electrically couple and suppress arrhythmias in injured hearts. Nature. (JOURNAL ARTICLE). (2012).

[30] Zimmermann, W. H, Schneiderbanger, K, Schubert, P, Didie, M, Munzel, F, Heubach, J. F, et al. Tissue engineering of a differentiated cardiac muscle construct. Circ Res. (Journal Article; Research Support, Non-U.S. Gov't). (2002). , 90(2), 223-30.

[31] Haraguchi, Y, Shimizu, T, Sasagawa, T, Sekine, H, Sakaguchi, K, Kikuchi, T, et al. Fabrication of functional three-dimensional tissues by stacking cell sheets in vitro. Nat Protoc. (Journal Article; Research Support, Non-U.S. Gov't). (2012). , 7(5), 850-8.

[32] Stevens, K. R, Pabon, L, Muskheli, V, \& Murry, C. E. Scaffold-free human cardiac tissue patch created from embryonic stem cells. Tissue Eng Part A. (Journal Article; Research Support, N.I.H., Extramural; Research Support, Non-U.S. Gov't). (2009). , 15(6), 1211-22.

[33] Ott, H. C, Matthiesen, T. S, Goh, S. K, Black, L. D, Kren, S. M, Netoff, T. I, et al. Perfusion-decellularized matrix: using nature's platform to engineer a bioartificial heart. Nat Med. (Journal Article; Research Support, Non-U.S. Gov't). (2008). , 14(2), 213-21.

[34] Radisic, M, Park, H, Shing, H, Consi, T, Schoen, F. J, Langer, R, et al. Functional assembly of engineered myocardium by electrical stimulation of cardiac myocytes cultured on scaffolds. Proc Natl Acad Sci U S A. (Journal Article; Research Support, Non-U.S. Gov't; Research Support, U.S. Gov't, Non-P.H.S.; Research Support, U.S. Gov't, P.H.S.). (2004). , 101(52), 18129-34.

[35] Serena, E, Figallo, E, Tandon, N, Cannizzaro, C, Gerecht, S, Elvassore, N, et al. Electrical stimulation of human embryonic stem cells: cardiac differentiation and the generation of reactive oxygen species. Exp Cell Res. (Journal Article; Research Support, N.I.H., Extramural; Research Support, Non-U.S. Gov't). (2009). , 315(20), 3611-9.

[36] Tandon, N, Cannizzaro, C, Chao, P. H, Maidhof, R, Marsano, A, Au, H. T, et al. Electrical stimulation systems for cardiac tissue engineering. Nat Protoc. (Journal Article; Research Support, N.I.H., Extramural; Research Support, Non-U.S. Gov't). (2009). , $4(2), 155-73$.

[37] Leor, J, Tuvia, S, Guetta, V, Manczur, F, Castel, D, Willenz, U, et al. Intracoronary injection of in situ forming alginate hydrogel reverses left ventricular remodeling after myocardial infarction in Swine. J Am Coll Cardiol. (Journal Article; Research Support, Non-U.S. Gov't). (2009). , 54(11), 1014-23.

[38] Ieda, M, Fu, J. D, Delgado-olguin, P, Vedantham, V, Hayashi, Y, Bruneau, B. G, et al. Direct reprogramming of fibroblasts into functional cardiomyocytes by defined fac- 
tors. Cell. (Journal Article; Research Support, N.I.H., Extramural; Research Support, Non-U.S. Gov't). (2010). , 142(3), 375-86.

[39] Chen, J. X, Krane, M, Deutsch, M. A, Wang, L, Rav-acha, M, Gregoire, S, et al. Inefficient reprogramming of fibroblasts into cardiomyocytes using Gata4, Mef2c, and Tbx5. Circ Res. (Journal Article; Research Support, N.I.H., Extramural; Research Support, Non-U.S. Gov't). (2012). , 111(1), 50-5.

[40] Mammoto, A, Connor, K. M, Mammoto, T, Yung, C. W, Huh, D, Aderman, C. M, et al. A mechanosensitive transcriptional mechanism that controls angiogenesis. Nature. (Journal Article; Research Support, N.I.H., Extramural; Research Support, NonU.S. Gov't; Research Support, U.S. Gov't, Non-P.H.S.). (2009). , 457(7233), 1103-8.

[41] KshitizHubbi ME, Ahn EH, Downey J, Afzal J, Kim DH, et al. Matrix rigidity controls endothelial differentiation and morphogenesis of cardiac precursors. Sci Signal. (Journal Article; Research Support, N.I.H., Extramural; Research Support, Non-U.S. Gov't). (2012). a41.

[42] Gnecchi, M, Danieli, P, \& Cervio, E. Mesenchymal stem cell therapy for heart disease. Vascul Pharmacol. (Journal Article; Research Support, Non-U.S. Gov't). (2012). , 57(1), 48-55.

[43] Noiseux, N, Gnecchi, M, Lopez-ilasaca, M, Zhang, L, Solomon, S. D, Deb, A, et al. Mesenchymal stem cells overexpressing Akt dramatically repair infarcted myocardium and improve cardiac function despite infrequent cellular fusion or differentiation. Mol Ther. (Journal Article; Research Support, N.I.H., Extramural; Research Support, Non-U.S. Gov't). (2006). , 14(6), 840-50.

[44] Mazhari, R, \& Hare, J. M. Mechanisms of action of mesenchymal stem cells in cardiac repair: potential influences on the cardiac stem cell niche. Nat Clin Pract Cardiovasc Med. (Journal Article; Research Support, N.I.H., Extramural; Research Support, NonU.S. Gov't). (2007). Suppl 1:S, 21-6.

[45] Lee, M. J, Kim, J, Kim, M. Y, Bae, Y. S, Ryu, S. H, Lee, T. G, et al. Proteomic analysis of tumor necrosis factor-alpha-induced secretome of human adipose tissue-derived mesenchymal stem cells. J Proteome Res. (Journal Article; Research Support, NonU.S. Gov't). (2010). , 9(4), 1754-62.

[46] Valadi, H, Ekstrom, K, Bossios, A, Sjostrand, M, Lee, J. J, \& Lotvall, J. O. Exosomemediated transfer of mRNAs and microRNAs is a novel mechanism of genetic exchange between cells. Nat Cell Biol. (Journal Article; Research Support, Non-U.S. Gov't). (2007). , 9(6), 654-9.

[47] Alvarez-erviti, L, Seow, Y, Yin, H, Betts, C, Lakhal, S, \& Wood, M. J. Delivery of siRNA to the mouse brain by systemic injection of targeted exosomes. Nat Biotechnol. (Journal Article; Research Support, Non-U.S. Gov't). (2011). , 29(4), 341-5. 